\title{
Ortaokul Çağında Benlik Saygısının Cinsiyet, Sınıf Düzeyi Babalık Rolü Algısı ve Eğitim Düzeyine Göre İncelenmesi
}

\author{
DOI: 10.26466/opus.787450 \\ * \\ Havva Özkan* \\ * Psikolojik Danışman, Istanbul Aydın Üniversitesi \\ E-Posta: psk.havvaozkan@gmail.com \\ ORCID: $\underline{0000-0003-3818-7328}$
}

\begin{abstract}
$\ddot{O} z$
Bu araştırmanın amacı, ortaokul çă̆ındaki ergenlerin benlik saygılarının; cinsiyet, sımf düzeyleri, babalarının babalık rolü algıları ve eğitim düzeyleri değişkenlerine göre incelenmesidir. Araştırma, 20192020 eğitim öğretim yılında 5,6,7 ve 8. sinı düzeylerinde bulunan 100 ögrrenci ve ortaokul seviyesinde çocuğu bulunan 100 baba üzerinde yapılmıştır. Araştırmada ilişkisel tarama modeli kullanılmıştır. Ö̆̆ rencilere 'Offer Benlik Imgesi Ölçeği' ve 'Ergen Baba İlişki Ölçeği', babalara ise 'Babalık Rolü Algı Ölçeği' uygulanmıştır. Uygulanan ölçeklerin istatistiki analizlerinde SPSS 20.0 programı kullanılmıştır. Araştırma sonucunda elde edilen bulgulara göre; kız ergenler benlik saygisını oluşturan alt unsurlarda erkek ergenlere göre daha yüksek puanlar almışlardır. Babalar erkek çocuklarıyla daha yakın ilişki kurmakta ve kız çocuklarına göre daha fazla özgürlük tanımaktadırlar. Ayrıca babaların çocuklarına karşı babalık rolü algılarında yaşlarına, eğitim düzeylerine ve çocuklarının sınıf düzeylerine göre anlamlı bir farklılık olmadığ da elde edilen bulgular arasındadır. Araştırmanın sonuç bölümünde babalık rolü algısı ile ilgili nedenler tartışılmış ve önerilerde bulunulmuştur. Özellikle babalara yönelik Ĕ̆itim verilerek, babalık röl ve görevleri hakkında bilgilendirilmeleri gerekmektedir. Babaları çocukların gelişim dönemi özelliklerinden özellikle ergenlik dönemine yönelik farkıdalıklarının kazandırılması için gerekli eğitim, çalışma ve projelerle desteklenmesi gerekmektedir. Bu faaliyetler sayesinde ergenlerin benlik saygılarında ve özgüvenlerinin gelişiminde olumlu yönde büyük gelişmelerin olacağı düşünülmektedir.
\end{abstract}

Anahtar Kelimeler: Ergenlik, benlik saygısı, babalık rolü 


\title{
Review Of Self-Esteem At Secondary School Age With Respect To Gender, School Grade Level, Perception Of Fathering Role And Educational Level
}

\begin{abstract}
This study aims to review self-esteem level of adolescents according to the variables of their class level, gender and their fathers' paternity role perception and education level. It was conducted in 2019-2020 school year with 100 students studying at 5th, 6th, 7 th and 8 th classes and 100 fathers who have a child at secondary school. The data in this study, which uses a relational screening model, were collected through 'Offer Self-Image Scale" and 'Parent-Adolescent Relation Scale' applied to the students and 'Father's Paternity Role Perception Scale' applied to the participant fathers. These scales were statistically analyzed on SPSS 20.0 software. The results obtained in the study show that in the sub-dimensions of the self-esteem female adolescents had higher scores than male adolescents. Fathers have closer relations with their sons and allow them more freedom than they do for their daughters. However, findings obtained in the study show that fathers' paternity role perception towards their children do not significantly differ depending on age, educational status and children's class level variables. Discussion about the reasons affecting the fathers' paternity role perception and recommendations are given in the results part of the study. Especially fathers should be informed about the role and duties of paternity by providing training. Fathers should be supported with the necessary education, studies and projects in order to raise awareness among the developmental period characteristics of the children, especially for the adolescence period. Thanks to these activities, it is thought that there will be great improvements in the selfesteem and self-confidence development of adolescents.
\end{abstract}

Keywords: Adolescence, self-esteem, fathers' paternity role 


\section{Giriş}

Birey doğumdan yaşlılığa kadar her biri farklı gelişim görevleri içeren dönemlerden geçer. Her dönem ayrı ayrı incelenmesi gereken kendine özgü özellikler göstermektedir. Ancak ergenlik dönemi eskiden beri bilimin ilgi alanına giren, üzerinde değişik açlardan araştırma ve görüşlerin yapıldı̆̆ı bir dönem olmuştur. Çünkü ergenlik dönemi başlamasından bitimine kadar yoğun bocalama ve uyum çabaları gerektirmektedir. Ergenlik dönemini sağlıklı geçiren birey, yaşamının diğer dönemlerinde de gereken gelişim görevlerinde daha olumlu ilerleme göstermektedir. Ergenlik dönemi her açıdan değişim ve bocalama içeren bir dönem olduğu için ele alınması ve tanımlanması da çeşitli bakış açları getirmektedir. Birey doğumdan itibaren yerine getirmesi gereken farklı gelişim görevlerinin yanı sıra benlik kavramını ve buna bağlı olarak da kişiliğini oluşturma uğraşı içinde kişilik oluşturma uğraşı özellikle ergenlik dönemine girişle daha önemli hale gelmektedir(Dinçel, 2006).

Ergenlik dönemi ile ilgili kuramsal bakış ve tanımlar incelendiğinde değişik dönemlerde, dönemin özellikleri, gençlere yaklaşım tarzı yapılan tanımlarda etkili olmuştur. Platon (İÖ.427-347) ergenlik dönemini üç katmalı olarak tanımlamıştır. Birinci katmanda nesnelere ilişkin kavrayış, ikinci katmanda kanalların gelişimi ve üçüncü katmanda ise ergenliğe ve yetişkinliğe bağlı olarak gelişen akıl ve zeka gelişimi olarak tanımlarken; John Lock (16321704) ise, ergenliği bilişsel etkinlik olarak tanımlamaktadır. Jean-Jacques Rousseau (1712-1778) insan gelişimini evrelere ayırmış ve (12- 15 yaşlar)'ı gençlik, (15-20 yaşlar)' ise ergenlik dönemi olarak tanımlamıştır. Ülkemizde ergenlik dönemi ve özelliklerine yönelik II. Meşrutiyet döneminden itibaren ilgi artmış özellikle anne baba ve eğitimcilerin ergenlere yaklaşımının nasıl olması gerektiği konusunda gerekli öneriler dönemin süreli yayınlarında yer almıştır(Karagöz, 2018). İbrahim Alaeddin tarafından 1919 yılında Tedrisat mecmuasında İlk Gençlik Psikolojisi 1,2,3,4 başlığı altında yayınlamış olduğu makalelerinde modern rehberlik anlayışına uygun olarak öğretmenlerin ve velilerin ergenlere nasıl davranması gerektiğini vurgulamıştır( Karagöz, 2016). Hall'da evrelere değinerek, gençlik ya da ön ergenlik (8- 12 yaşlar) ve ergenlik (13- 24 yaşlar) olarak ayrım yapmıştır. Yine Hall'a göre; gençlikte ya da ön ergenlikte kişisel denetimi öğrenme eğilimi ve çeşitli alışkanlıklar or- 
taya çıkar, ergenlik geleceğe yön veren toplumsal rollerin belirlenip benimsendiği, değer oluşumun yaşandığı bir dönemdir(Onur, 2019). Bu görüşü destekler nitelikte Sadrettin Celal Antel'in Cumhuriyetin İlk dönemlerinde "Maarif İçin On Yıllık Inkişaf Planı(1926)"nda dile getirdiği gibi günümüz anlamıyla bireylerin kendilik değeri ve benlik oluşumunda ailenin ve okulun görevlerine dikkat çekmiştir( Karagöz,2020).

İlerleyen çağlarda ergenlik konusunda tanımlama yapılırken ise, cinsel dürtüler, ego uyumu, kimlik oluşturma uğraşları üzerinde durulmaya başlanmıştır. Sigmund Freud(1856-1939)'a göre; genital evre, ergenlik döneminin yani 12-18 yaşların tümünü kapsar ve cinsel doyumun yetişkine özgü yollarıyla aşırı derecede uğraşma ve cinsel dürtülerin belirgin biçimde artması ile nitelenir. Sullivan'da yine ergenlik döneminden söz ederken evrelere ayırmıştır. Ona göre, ön ergenlik, yakın arkadaşlı̆̆a ilginin belirginleştiği, erken ergenlik, gerçek cinsel ilginin ortaya çıktığı, geç ergenlik ise cinsel davranışına yönelik tercih yaptığı ve cinsel kimliğini oluşturma aynı zamanda cinsel kimliğini fark etme dönemidir(Gençtan, 1995; Özbay, 2000; akt. Dinçel, 2006).

Günümüzde ise ergenliğin tanımı daha geniş kapsamlı olarak yapılmaktadır. Kulaksızoğlu (1998) ergenlik dönemini bedence büyümenin hızlandı̆̆1 buluğa girmekle başlayıp yine bedence büyümenin sona ermesiyle biten özel bir evre olarak tanımlamaktadır. Bedence büyümenin yanı sıra cinsel, duygusal, sosyal gelişim gibi alanlarda da önemli değişiklikler ve gelişmeler olmaktadır. Senemoğlu (1997)’a göre ergenlik dönemi; ön ergenlik, ergenlik ve son ergenlik olarak üç evreye ayrılarak tanımlanabilir. Ön ergenlik döneminde başlayan fiziksel, bilişsel ve psikolojik gelişmeye uyum sağlama çabaları vardır ve bu süreç ergenlik döneminde de devam etmektedir. Son ergenlik döneminde ise birey yetişkin hayatının sorumluluklarına geçiş yapmaktadır. Ergen psikolojik, fizyolojik ve zihinsel alandaki hızlı gelişim ve değişimlerle mücadele etmek zorundadır. Geçmişten günümüze kadar ergenlikle ilgili tanımlamalara bakıldığında çocukluk evresinden çıkan birey tüm gelişim alanlarındaki hızlanan değişimlere uyum sağlama çabası içinde aynı zamanda kimlik oluşturmaya çalışmaktadır. Bundan dolayı Erikson (1902) ergenliği bireyin Ben kimim? gibi soruları içeren bir araştırma, içe bakış ve keşfetme dönemi olarak tanımlamalar yapmaktadır (Onur, 1997).

Ergenlik dönemi gelişim özelliklerine bakıldığı zaman, ergenlik dönemini kapsayan 12-16 yaşlar arasında fiziksel değişim yoğunluk kazanmaktadır. Bu 
değişikliklere uyum sağlamak çabasında olan ergende çeşitli sakarlıklar da görülebilmektedir. (Senemoğlu, 1997).

Koç (2004)' te de belirtildiği üzere, Türkiye'de ergenlerin kendi bedenleri ile ilgili memnun olma düzeyleri ve benlik saygıları arasında anlamlı ilişkilerin olduğunu gösteren araştırmalar ergenlik döneminde fiziksel gelişim ve değişimin ergen için önemli bir konu olduğunu açılamaktadır. Ergenlik döneminde duygusal gelişim, bilişsel gelişim, ahlaki gelim ve sosyal gelişim olmak üzere dört gelişim alanından bahsedilebilir. Ergenlerin duygusal yapılarındaki gelişim, aile tutumları, arkadaşlık ilişkileri, yaş grubu gibi çeşitli faktörlere bağlı olarak dalgalanmalar göstermektedir. Ergenlik dönemine girmekle birlikte ana-babaya olan duygusal yakınlıkta gerileme ve çatışmalar olmaktadir.

Smith (2017)'de belirtildiği üzere, Ergenin özerlik arayışı ve ana babanın kontrol sağlama çabaları konusunda Amerikalı ergenler üzerinde yapılan bir araştırmada; ana babanın gence daha erken yaşlarda özerklik tanıdığı ailelerde ergenlerin kendilerini ana babalarına daha yakın hissettikleri ve daha yüksek özgüvene sahip oldukları bulunmuştur.

Bilişsel gelişim, bireyin çevresini ve dünyayı anlaması, öğrenmesi gibi zihinsel faaliyetlerle ilgili ve ömür boyu devam eden gelişim alanı olarak tanımlanabilmektedir. Bilişsel gelişim, doğumdan yetişkinliğe devam eden bir süreçtir. Bireylerin bilişsel gelişimleri konusunda bulunan kuramlardan ön plana çıkan Piaget'nin bilişsel gelişim kuramında soyut işlemler dönemi olarak adlandırdığ 11 yaş ve sonrasında ergen kendi değerler ve inanç sistemini yapılandırma, çeşitli etkinliklerde düşüncesiyle kendini gösterme eğiliminde olur (Senemoğlu, 1997).

Ergenliğe yaklaşmakla birlikte, kendi mantık ve vicdanına göre değerlendirme yapma eğilimi görülebilmektedir. Ergen çevresinde karşılaştığı bazı toplumsal kuralları eleştirerek, bazılarına ise uyum sağlayarak kendi kişilik yapısını oluşturmaya ve buna yönelik bir benlik kavramı geliştirmeye çalışmaktadır. Ahlaki gelişimin etkisi, çevre ile ilişkilerde ve bireyin benlik sayg1sında da görülmektedir. Uyumsuzluk gösteren, otoriteye karşı gelme davranışını sıklıkla gösteren gençte, çevrenin eleştirileri ve olumsuz değerlendirmelerinin fazla olması neticesinde düşük benlik saygısı oluşma ihtimali yüksek olacaktır (Koç, 2004). 
Sosyal gelişim, bilindiği üzere bireyin sosyalleşmesi ilk başta aile içinde başlar. Ergenlik dönemi ile birlikte sosyalleşme süreci aileden okul ve arkadaş çevresine çıkar. Ergen için arkadaşlıkları sosyalleşme açısından aileden daha ön plana gelmeye başlar(Bozyiğit, 2015).

Hortaçsu (1997)' e göre; ergenin arkadaş grubunu içinde bulunduğu sosyal çevre, aile yapısı, ailenin sosyo ekonomik durumu, ailenin eğitim öğretim düzeyi ve aile içindeki ilişkiler belirlemektedir.

Ergen yukarıda kısaca bahsedilen gelişim ve değişim alanlarına uyum sağlamaya çalışırken aynı zamanda benliğini oluşturma çabası içinde bulunmaktadır. Benlik kavramı bebeklikten itibaren bireyin çevresiyle iletişimi sonucu oluşan bir süreçtir. Bebeklikte ebeveynin tutumu ve sonra da çevredeki diğer insanların bize karşı söz, tutum ve davranışları benlik kavramı oluşturmamızda etkilidir (Gençtan, 1981).

Geçtan (1981), çevremizdeki insanların bize hissettirdiklerine göre benlik kavramımızı oluşturduğumuzu ve bu benlik kavramına göre kendimizi tanımladığımızı ifade etmektedir.

Benlik kavramının alt boyutları vardır ve genel olarak benliğin oluşması için bu unsurların oluşması ve birbirini tamamlaması gerekmektedir.

\section{Benlik Kavramının Unsurları}

Genel olarak yapılan tanımlamalara bakıldığında kişinin benlik saygısı hayatının ilk dönemlerinde ebeveynler ve çevre tarafından nasıl görülmüşse o şekilde oluşur. Birey kendini başarılı, kabul gören, sevilen bir kişi olarak da tanımlayabilir ya da başarısız, istenmeyen, değersiz bir kişi olarak da görebilir. İlk başta oluşan bu düşük ya da yüksek benlik saygısı hayatın diğer alanlarındaki yaklaşım, tutum ve davranışları da etkilemektedir. Benlik kavramını etkileyen çeşitli faktörlerin olduğu bilinmektedir. Bu faktörler arasında annebaba tutumları ve ergen- aile ilişkileri de yer almaktadır. Benlik kavramı ile bağlantılı olan benlik saygısı kavramı da bireyin içinde doğup büyüdüğü aile ortamindan etkilenmektedir(Erbil, Divan ve Önder,2006).

Sancar(2016 tarafından yapına sınıflamaya göre benlik kavramı benlik imgesi, ideal benlik ve benlik saygısı olarak ele alınmıştır. Benlik Imgesi: Doğumdan itibaren bireyin aile içindeki tutumlar ve onun hakkındaki sık kullandığı ifadeler bireyin kendisi hakkında bir imge oluşmasını sağlamaktadır. İdeal 
Benlik: Genellikle toplum tarafından oluşturulmuş standart özellik ve davranışlardır. Benlik Saygısı: Bireyin kendisini nasıl tanımladığı ve nasıl olmak istediği arasındaki farkın ölçüsü onun benlik saygısını ifade etmektedir.

Bu çalışmanın ana konusu Benlik saygısı ile ilişkili olduğundan bu kavramın daha ayrıntılı açıklanmasına gerek duyulmuştur. Benlik kavramını oluşturan unsurlardan benlik imgesi fiziksel özelliklerle, ideal benlik toplumun beklediği olması gereken benlik iken; benlik saygısı kişinin kendisiyle ilgili sahip olduğu duygusal boyut ile daha çok ilgili olmaktadır. Bu konuda literatürde birçok tanımlama yapılmıştır. Coopersmith (1967) benlik saygısının gelişiminde ebeveynlerin rolü üzerinde çalışmalar yapmış ve ebeveynin çocuğa gösterdiği ilgi, kabul, çocuktan beklentileri, çocuk yetiştirme yöntemlerinin benlik saygısında önemli olduğunu ifade etmiştir. Rosenberg (1986)'e göre ise benlik saygısı bireyin çevresinin yansıttığı olumlu ve olumsuz tutumlara göre oluştuğu için kişilerarası davranış ve tutumları ön plana alınarak tanımlama yapılmalıdır. (Pişkin, 2003).

Yörükoğlu (2004), benlik saygısı yüksek olan gençlerin kendilerini başkaları tarafından sevilen, arkadaş olarak tercih edilip saygı duyulan, iyi olarak tanımladıklarını ifade ederken Yavuzer (2000), düşük benlik saygısı olan gençlerin eleştirilere açık olmayan, görev ve sorumluluklardan kaçınan, akran ilişkilerinde zorluklar yaşayan bireyler olarak tanımlamaktadır. Ergenlerin Benlik Saygısı ile ebeveynin benlik saygısı arasında ilişki olup olmadığına yönelik yapılan araştırma sonucunda, ergenin benlik saygısı ile annenin benlik saygısı arasında anlamlı bir ilişki olduğu tespit edilmiştir. (Dilek, Aksoy,2013).

Yörükoğlu (1986)'da da belirtildiği gibi, yapılan araştırmalara genel olarak bakıldığında ergenlerin benlik saygılarında duygusal, bilişsel, toplumsal ve bedensel olmak üzere belli başlı faktörlerin etkili olduğu görülmektedir. Birey doğumundan itibaren aile içinde benlik saygısının temellerini atmaya başlar. Buraya kadar yapılan tanımlama ve açıklamalar ışı̆̆ında ergenin benlik saygısı üzerinde aile ortamı ve ebeveyn tutumlarının son derece etkili olduğu görülmektedir. Anne-baba tutumlarının farklılı̆̆ına dayalı olarak ergenin de edindiği benlik saygısı farklılık göstermektedir.

Ergenlerin Benlik Saygısına Ailelerinin Tutum ve Davranışlarmmn Etkisi' ni belirlemeye yönelik araştırma sonucunda; aile ile iyi ilişkileri olan, kararlara katılan, kendilerine ve görüşlerine saygı duyulan, kız-erkek ayrımının olmadığı, aileleriyle her konuda konuşmaktan çekinmeyen ve demokratik ailelere 
sahip ergenlerde benlik saygısının daha yüksek olduğu görülmüştür (Erbil, Divan, Önder, 2006).

Yavuzer (1990)'a göre, demokratik aile ortamında çocuk duygusal, sosyal ve zihinsel olarak olumlu gelişim gösteren, sağlıklı ve dengeli kişilik geliştirmektedir. Koruyucu/ istekçi anne baba tutumunda ise, anne baba çocuğunu aşırı denetler ve her şeyi çocuğun yerine kendisi yapmaya çalışır. Böylece çocuk girişimcilikten uzak ve kendi kendine karar veremeyen, bağımlı birey olarak yetiştirilir.

Başaran (1984)' e göre, 20. yüzyıldan önce ülkemizde geleneksel yani babanın evin geçimini sağlamak için çalışan ve evde otoriter olan, annenin ise ev işleri ve çocuklarla meşgul olduğu bir aile yapısı bulunmaktaydı. Ancak toplumsal değişim ve gelişim olması sayesinde kadının da çalışma hayatına girmesiyle birlikte aile hayatındaki rollerde ve tutumlarda değişim gerçekleşmiştir.

Kadının çalışma hayatına girmesi ile ev işleri ve çocuklarla ilgilenme gibi konularda destek ihtiyacının ortaya çıkmasıyla, babanın da ev içinde rolünde değişimlere neden olmuştur. Yirminci yüzyılın ikinci yarısından sonra aile içinde babanın rolünün ve babalık algısının değişmesiyle birlikte çocuklarıyla daha fazla vakit geçiren babaların çocuklarının gelişimleri üzerindeki etkileri merak konusu olmuş ve bu konuda yapılan araştırma sayısında artış meydana gelmiştir.

Buna bağlı olarak babanın da ev içinde rolünde değişimler gerekli olmuştur. Yirminci yüzyılın ikinci yarısından sonra aile içinde babanın rolünün ve babalık algısının değişmesiyle birlikte çocuklarıyla daha fazla vakit geçiren babaların çocuklarının gelişimleri üzerindeki etkileri merak konusu olmuş ve bu konuda yapılan araştırma sayısında artış meydana gelmiştir.

Kuzucu (1999)' da açıklandığı gibi, babanın çocuğun gelişim özelliklerinde etkililiğini konu alan araştırmalarda çocuğuyla daha fazla ilgilenen babaların çocuklarının zihinsel, bilişsel, sosyal, duygusal gelişimlerinde olumlu etkileri olduğu belirlenmiştir.

$\mathrm{Bu}$ araştırmanın konusunda önemli bir yere sahip olan Babalık Rolü Algısı ergenin yaşamını etkileyen faktörler arasındadır. Çünkü ergenin babasının aile içinde kendi rolü ile ilgili görüş ve yaklaşımları ergenin kendisiyle ilgili algısından, çevresiyle ilişkisine ve birçok durumdaki tutum ve davranışlarında etkili olmaktadır. Babaları ile iletişim ve ilişki boyutunda sorun yaşamayan ergenlerin, uyum konusunda sorun yaşamadığı, benlik saygılarının 
daha yüksek olduğu, okulda daha başarılı olduğu ve antisosyal kişilik bozukluğu göterir davranışları daha az gösterdiğine yönelik ilgili literatürde çok sayıda çalışma bulgularıyla karşılaşılmaktadır. (Erdoğan, 2004, akt. Kuruçay, 2012).

Aksoy (2019)' da belirtildiği gibi değişen babalık rolünün önemine yönelik yapılan araştırmalar babaların geleneksel babalık rolü algısından uzaklaştıklarında çocuklarıyla daha yakından ilgilenip yakın ilişkiler kurabildiklerini göstermektedir.

Buraya kadar yapılan açıklamalarda ergenlik döneminin zorlu bir süreç olduğu ve bu süreçte ergenin olumlu benlik saygısı geliştirebilmesi açısından anne-baba tutumlarının, ergenin ebeveyniyle ilişkilerinin önemi anlatılmaya çalışılmıştır. Ayrıca günümüzde değişen aile içi rollere dayanarak babanın da çocuklarıyla daha fazla ilgilenmesi ve yakın ilişki kurmasının ergenlik döneminde artan bir öneme sahip olduğundan bahsedilmiştir. Peki bu rol değişimi ve babalık rolü konusunda babaların algıları ne boyuttadır? Sorusuna cevap bulmak için aşağıdaki hipotezlerin doğruluğuna bakılmıştır.

$\mathrm{Bu}$ araştırma babaların, babalık rollerindeki algılarına göre çocuklarının benlik saygıları üzerindeki etkileri ve ergen-baba ilişkisinin önemi konusunda farkındalık kazanmalarını sağlamak açısından önemli olduğu düşünülmüştür. Bu amaçla, ortaokul çağında (11-14 yaş), ergenliğin ilk döneminde bulunan öğrencilerin benlik saygılarında, babalarının babalık rolünü algılamaları ve eğitim düzeyleri ile öğrencinin sınıf düzeyine göre farklılık olup olmadığını belirlemek amacıyla aşağıdaki hipotezler oluşturulmuştur:

- H-1 Benlik saygisında cinsiyete göre farklılık göstermektedir.

- H-2 Benlik saygısında sinıf düzeyine göre farklılık göstermektedir

- H-3 Babalık rolü algısında, babanın eğitim düzeyinin etkisi vardır.

- H-4 Babalık rolü algısında, çocuğunun sınıf düzeyiyle ilgisi vardır.

Bu hipotezler doğrultusunda şu varsayımlarda bulunulmuştur.

1. Araştırma kapsamına alınan ergenlerin, 'Offer Benlik İmgesi Ölçeği' ni ve 'Baba Ergen İlişki Ölçeği' ni; babalarının ise 'Babalık Rolü Alg1 Ölçeği' ni içtenlikle ve gerçek düşünce ve duygularını yansıtacak şekilde cevapladıkları varsayılmaktadır.

2. Örneklemin evreni temsil ettiği varsayılmaktadır.

3. Araştırmada kullanılan veri toplama araçlarının, araştırmanın amacına uygun olduğu varsayılmıştır. 


\section{Yöntem}

\section{Araştırma Modeli}

Bu çalışmanın doğası gereği araştırmada İlişkisel Tarama Modeli kullanılmıştır. İlişkisel Tarama Modeli; iki ya da daha çok sayıdaki değişken arasında birlikte değişim varlığını ve/ veya derecesini belirlemeyi amaçlayan araştırma modelleridir (Küçük, 2016, s:134).

\section{Evren ve Örneklem}

Bu araştırmanın çalışma evrenini; Kayseri il merkezinde, 75. Yıl Mühibe Germirli Ortaokulu, Erciyes Ortaokulu, Kadir Has Ortaokulu oluşturmaktadır. Örneklem ise, bu ortaokullarda 2019-2020 eğitim öğretim yılında 5.,6.,7., ve 8. Sınıflarda bulunan tesadüfi olarak seçilmiş öğrenciler ve babaları oluşturmaktadir.

\section{Veri Toplama Araçlam}

Offer Benlik İmgesi Ölçeği: Ölçeğin özgün adı, Offer Self-Image Questionnaire ( OSIQ ) dir. D. Offer, E. Ostrov, K.I. Howard ve S. Dolan tarafından ilk kez 1962 yılında Offer ve arkadaşları tarafından lise öğrencilerinden oluşan geniş bir grup üzerinde normal ergenlik özelliklerini saptamak amacıyla geliştirilmiştir.

Ölçeğin 130 maddelik çevirisini Banu İnanç yapmıştır. Çuhadaroğlu, Sonuvar ve Özusta'nın 1992 yılındaki araştırmasında ölçek üç farklı sosyo-ekonomik düzeyde 12-21 yaşları arasındaki 453 gence uygulanarak OBİÖ kullanım kitabındaki önerilere uygun şekilde normatif grup değerleri, yaş ve cinsiyete göre grup normları elde edilmiş ve standart puan cetvelleri çıkarıldığı görülmektedir. OSIQ-99'da ergenler, kendilerini tanımlama derecesine göre, "çok iyi "den başlayarak "hiç" e kadar giden 6 seçenekten birini işaretleyerek yanut verirler. Olumlu ifadelere "bana hiç uygun değ il" diyenlerle, olumsuz ifadelere "bana çok uygun" diyenleri ayn yönde değerlendirebilmek amacılla olumsuz ifadelerin seçeneklerine verilen cevapların analizi sırasında puanlar oluşturulurken, sayısal değerleri tersine çevrilmektedir.

Babalık Rolü Algı Ölçeği: Kuzucu (1999) yılında tarafından Babalık Rolü Algı Ölçeği'ni 5 dereceli Likert türünde geliştirilmiştir. Ölçekte babalık rolü algısı 
14 olumlu, 11 olumsuz olarak 25 maddeden oluşmaktadır. Ölçekte 1- Hiç Uygun Değil, 2- Pek Uygun Değil, 3- Kararsızım, 4- Kısmen Uygun, 5- Tamamen Uygun seçenekleri bulunmaktadır. Ölçeğin puanlamasında 1' den 5'e doğru olumlu maddeler, $5^{\prime}$ ten $1^{\prime}$ e doğru olumsuz maddeler dikkate alınmıştır (Aksoy ve Tatl, 2019).

Baba - Ergen İlişkisi Ölçeği: Ergenlik döneminde özerklik kazanma sürecinde ergen-anne ve ergen- baba iletişimi arasında farklılıklar olup olmad1ğını araştırmak amaciyla, 2002 yılında Demet Öngen tarafindan geliştirilen ölçekte bulunan 60 maddenin 30'u ters puanlanmak üzere düzenlenmiştir. Dörtlü likert tipi bir ölçek üzerinde, deneklerden "Bana tamamen uygun=l", "Bana uygun=2", "Bana uygun değil=3" ve "Bana hiç uygun değil=4" seçeneklerinden birini işaretleyerek belirtmeleri istenmiştir. Puanın düşmesi ergene daha fazla sevgi gösterildiğinin ve daha fazla özgürlük tanındığının göstergesi olmaktadır. Ölçekte yer alan sevgi gösterme maddesinin alt boyutları olarak, sevgi, güven, gurur, kabul, anlayış, birlikte zaman geçilme, duyguların, düşüncelerin ve sorunların paylaşımı yer almıştır. Örneğin: Babam olumlu yönlerimi sık sık över.

Ölçeğin özgürlük tanıma maddesinin alt boyutlarında ise, Özgürlük tamına, özel yaşama saygı, kontrol, eleştiri, denetleme, bask ve yaptırım uygulama, ceza verme ile ilgili alt boyutlar yer almıştır. Örneğin: Babam kendi istediğgi gibi giyinmem konusunda bana baskı yapar.

\section{Verilerin Analizi}

Araştırmada 5.,6.,7. Ve 8. sınıf öğrencilerine ‘Offer Benlik İmgesi Ölçeği' ve 'Baba Ergen İlişki Ölçeği; babalarına ise ‘Babalık Rolü Algı Ölçeği' uygulanmıştır. Ölçeği 100 öğrenci ve babaları cevaplamıştır. 100 öğrenci ve babadan elde edilen verilerin analizinde SPSS 20.0 programı kullanılmıştır.

Ortaokul çağındaki ergenlerin benlik saygıları ile babalarının rollerine ilişkin algıları ve eğitim düzeyleri arasında ilişkinin olup olmadığının incelendiği araştırmada; elde edilen verilerin normal dağılıma uygun olup olmadığını analiz etmek için, Kolmogorov-Smirnov ve Shapiro-Wilk kullanılmıştır. Katılımcıların 'Offer Benlik İmgesi Ölçeği' alt boyutları arasında anlamlı ilişkiye ait "Spearman Korelasyon Analizi' yapılmıştır. 'Babalık Rolü Algısı Ölçeği' ni cevaplayan katılımcların eğitim durumları ve sınıf değişkenlerine ilişkin bağımsız örneklemler için 'Kruskal-Wallis H Analizi' yapılmıştır. 'Er- 
gen Baba İlişki Ölçeği' ni cevaplayan katılımcıların cinsiyet düzeyleri değişkenlerine ilişkin bağımsız örneklemler için 'Mann-Whitney Analizi' yapılmıştır. İstatistiki kavramların kısaltılmasında frekans (F), geçerli yüzde (G.Y.) ve Yığılmalı Yüzde (Y.G.) şeklinde gösterilmiştir.

\section{Bulgular}

Tablo 1. Katılımcılarnn eğitim durumu değişkenine ilişkin bulgular

\begin{tabular}{lllll}
\hline Eğitim Durumunuz & \multicolumn{3}{l}{} \\
\hline Illkokul & F & Yüzde & G.Y & Y.G. \\
\hline Ortaokul & 9 & 9,0 & 9,0 & 9,0 \\
\hline Lise & 17 & 17,0 & 17,0 & 26,0 \\
\hline Ön lisans & 32 & 32,0 & 32,0 & 58,0 \\
\hline Lisans & 14 & 14,0 & 14,0 & 72,0 \\
\hline Toplam & 28 & 28,0 & 28,0 & 100,0 \\
\hline
\end{tabular}

Tablo 1 incelendiğinde, Babalık rolü testi puan ortalamalarına ilişkin olarak katılımcıların eğitim durumlarına göre katılım oranlarına bakıldığında en çok katılımın \%32 ile lise düzeyine, en düşük katılımın ise \%9 ile ilkokul düzeyinde olduğu görülmektedir.

Tablo 2. Katılımcılarnn cinsiyet değişkenine ilişkin bulgular

\begin{tabular}{lllll}
\hline Cinsiyetiniz & \multicolumn{1}{l}{} \\
\hline & F & Yüzde & G.Y & Y.G. \\
\hline Kuz & 59 & 59,0 & 59,0 & 59,0 \\
\hline Erkek & 41 & 41,0 & 41,0 & 100,0 \\
\hline Toplam & 100 & 100,0 & 100,0 & \\
\hline
\end{tabular}

Tablo 2 incelendiğinde, Ergen Baba İlişkisi Ölçeğine katılan katılımcıların \%59'unun kız, \%41'inin ise erkek katılımcılardan oluştuğu görülmektedir.

Tablo 3. Katıllmcıların sımı değişkenine ilişsin bulgular

\begin{tabular}{lllll}
\hline Sinıf Düzeyi & \multicolumn{2}{l}{} \\
\hline & F & Yüzde & G.Y & Y.G. \\
\hline 5. Sinıf & 25 & 25,0 & 25,0 & 25,0 \\
\hline 6. Sinıf & 25 & 25,0 & 25,0 & 50,0 \\
\hline 7. Sinıf & 25 & 25,0 & 25,0 & 75,0 \\
\hline 8. Sinıf & 25 & 25,0 & 25,0 & 100,0 \\
\hline Toplam & 100 & 100,0 & 100,0 & \\
\hline
\end{tabular}


Tablo 4. Katılımcıların cinsiyet değişkenine ilişkin frekans tablosu

\begin{tabular}{lllll}
\hline Cinsiyetiniz & \multicolumn{3}{l}{} \\
\hline & F & Yüzde & G.Y & Y.G. \\
\hline Kız & 72 & 72,0 & 72,0 & 72,0 \\
\hline Erkek & 28 & 28,0 & 28,0 & 100,0 \\
\hline Toplam & 100 & 100,0 & 100,0 & \\
\hline
\end{tabular}

Tablo 4 incelendiğinde, Offer Benlik İmgesi Ölçeği' ne katılan katılımcıların \%72'sinin kız, \%28' inin ise erkek katılımcılardan oluştuğu görülmektedir.

Tablo 5. Katılımcıların sınıf değişkenine ilişkin bulgular

\begin{tabular}{lllll}
\hline Sinıfınız & & & & \\
\hline & F & Yüzde & G.Y & Y.G. \\
\hline 5. Sinif & 25 & 25,0 & 25,0 & 25,0 \\
\hline 6. Sinıf & 25 & 25,0 & 25,0 & 50,0 \\
\hline 7. Sinif & 25 & 25,0 & 25,0 & 75,0 \\
\hline 8. Sinıf & 25 & 25,0 & 25,0 & 100,0 \\
\hline Toplam & 100 & 100,0 & 100,0 & \\
\hline
\end{tabular}

Araştırmada oluşturulan hipotezlerle ilgili bulgular ise aşağıda gösterilmiştir.

\section{H-1: Benlik Saygısında Cinsiyetlere Göre Farklılık Vardır}

Tablo 6. Cinsiyet Değişkeni Gruplarnna İlişkin Bağımsız Örneklemler için Mann-Whitney Testi Analiz Sonuçları

\begin{tabular}{|c|c|c|c|c|c|c|c|}
\hline Cinsiyet & & $\mathbf{N}$ & $\begin{array}{l}\text { Sira } \\
\text { Ortalamalanı }\end{array}$ & $\begin{array}{l}\text { Sum of } \\
\text { Ranks }\end{array}$ & $\begin{array}{l}\text { Mann- } \\
\text { Whitney U }\end{array}$ & $\mathrm{Z}$ & $\mathbf{P}$ \\
\hline \multirow{3}{*}{$\begin{array}{l}\text { Sevgi } \\
\text { Gösterme }\end{array}$} & Kız & 59 & 47,69 & 2813,50 & & & \\
\hline & Erkek & 41 & 54,55 & 2236,50 & 1043,500 & $-1,165$ & 244 \\
\hline & Toplam & 100 & & & & & \\
\hline \multirow{3}{*}{$\begin{array}{l}\text { Özgürlük } \\
\text { Tanıma }\end{array}$} & $\mathrm{K}_{\mathrm{z} z}$ & 59 & 50,02 & 2951,00 & & & \\
\hline & Erkek & 41 & 51,20 & 2099,00 & 1181,000 & $-0,200$ & 842 \\
\hline & Toplam & 100 & & & & & \\
\hline \multirow{3}{*}{ Genel Ort. } & $\mathrm{K}_{1 z}$ & 59 & 48,56 & 2865,00 & & & \\
\hline & Erkek & 41 & 53,29 & 2185,00 & 1095,000 &,- 803 & ,422 \\
\hline & Toplam & 100 & & & & & \\
\hline
\end{tabular}

Tablo 6 incelendiğinde katılımcıların; Sevgi gösterme alt boyutundan aldıkları ortalama puanları cinsiyete değerlendirildiğinde farklılık görülmemektedir.(U=1043,50 p>.05). Sıra ortalamalarına bakıldığında ise kız ergenlerin sevgi gösterme alt boyutundan aldıkları puanların $(47,69)$ erkek öğrencilerden $(54,55)$ daha düşük olduğu görülmektedir. Özgürlük tanıma alt boyutun- 
dan aldıkları ortalama puanları cinsiyete göre anlamlı bir fark göstermemektedir ( $\mathrm{U}=1181,00$ p>.05). Sıra ortalamaları dikkate alındığında kız öğrencilerin özgürlük tanıma alt boyutundan aldıkları puanların $(50,02)$ erkek öğrencilerin almış oldukları puandan $(51,20)$ daha düşük olduğu görülmektedir.

Genel ortalama puanına bakıldığında ise, katılımcıların aldıkları puanlar cinsiyete göre anlamlı bir fark göstermediğii( $U=1095,00$ p>.05). Ancak sira ortalamalarına bakıldığında kız öğrencilerin ortalama puanların $(48,56)$ erkek öğrencilerden $(53,29)$ daha düşük olması sevgi ve özgürlük konusunda erkeklerin daha avantajlı olduğu sonucuna ulaşılabilir.

Offer Benlik İmgesi Ölçeği' ni cevaplayan katılımcıların cinsiyet değişkeni farklılığına ilişkin bağımsız örneklemler için 'Mann-Whitney Analizi'yapılmıştır . Analize ilişkin bulgular aşağıdaki tablo 7 ve 8 ' de gösterilmiştir.

Offer Benlik İmgesi Ölçeği' ni cevaplayan katılımcıların cinsiyet değişkeni farklılı̆̆ına iliş̧kin bağımsız örneklemler için 'Mann-Whitney Analizi' sonuçları incelendiğinde Cinsel turumlar, bireysel değerler ve baş etme gücü boyutunda cinsiyete göre anlamlı farkın olduğu görülmüş̧ ancak aile sağlı̆̆ı, dürtü kontrolü alt boyutlarında ise anlamlı bir farklılık bulunmamıştır. Sonuçlara ilişkin veriler ise aşağıdaki tablo 7 'de gösterilmiştir.

Tablo 7. Offer Benlik İmgesi Ölçeği' ni cevaplayan katılımcılarnn cinsiyet değişkeni farklılı̆̆ına ilişkin bağımsız örneklemler için 'Mann-Whitney Analizi' sonuçlarn

\begin{tabular}{|c|c|c|c|c|c|c|c|}
\hline \multicolumn{2}{|c|}{ Cinsiyet } & $\mathbf{N}$ & $\begin{array}{l}\text { Sira } \\
\text { Ortalamaları }\end{array}$ & $\begin{array}{l}\text { Sum of } \\
\text { Ranks }\end{array}$ & $\begin{array}{l}\text { Mann- } \\
\text { Whitney U }\end{array}$ & $\mathrm{Z}$ & $\mathbf{P}$ \\
\hline \multirow{3}{*}{ Aile İlişkileri: } & $\mathrm{K} ı \mathrm{z}$ & 72 & 53,97 & 3885,50 & & & \\
\hline & Erkek & 28 & 41,59 & 1164,50 & 758,50 & $-1,952$ & 0,051 \\
\hline & Toplam & 100 & & & & & \\
\hline \multirow{3}{*}{$\begin{array}{l}\text { Dürtü } \\
\text { Kontrolü: }\end{array}$} & $\mathrm{K} ı \mathrm{z}$ & 72 & 53,01 & 3816,50 & & & \\
\hline & Erkek & 28 & 44,05 & 1233,50 & 827,50 & $-1,414$ & 0,157 \\
\hline & Toplam & 100 & & & & & \\
\hline \multirow{3}{*}{$\begin{array}{l}\text { Cinsel } \\
\text { Tutumlar: }\end{array}$} & $\mathrm{K} ı \mathrm{z}$ & 72 & 54,76 & 3943,00 & & & \\
\hline & Erkek & 28 & 39,54 & 1107,00 & 701,00 & $-2,410$ & 0,016 \\
\hline & Toplam & 100 & & & & & \\
\hline \multirow{3}{*}{$\begin{array}{l}\text { Bireysel } \\
\text { Değerler: }\end{array}$} & $\mathrm{K} ı \mathrm{z}$ & 72 & 56,29 & 4053,00 & & & \\
\hline & Erkek & 28 & 35,61 & 997,00 & 591,00 & $-3,265$ & 0,001 \\
\hline & Toplam & 100 & & & & & \\
\hline \multirow{3}{*}{$\begin{array}{l}\text { Baş } \\
\text { etme Gücü: }\end{array}$} & $\mathrm{K} ı \mathrm{z}$ & 72 & 54,76 & 3942,50 & & & \\
\hline & Erkek & 28 & 39,55 & 1107,50 & 701,50 & $-2,416$ & 0,016 \\
\hline & Toplam & 100 & & & & & \\
\hline
\end{tabular}


Katılımcıların Aile ilişkileri alt boyutundaki puanlar incelendiğinde cinsiyete göre anlamlı bir fark göstermediği görülmektedir ( $U=758,50$ p >.05). Sıra ortalamalarına bakıldığında kız öğrencilerin aldıkları puanların $(53,97)$ erkek öğrencilerin almış olduğu puanlardan $(41,59)$ daha yüksek olduğu ortaya çıkmıştır.

Dürtü Kontrolü alt boyutundaki puanlar arasinda cinsiyete göre fark görülmemektedir ( $U=827,50$ p>.05). Sıra ortalamalarına bakıldığında kız öğrencilerin aldıkları puanların $(53,01)$ erkek öğrencilerin almış olduğu puanlardan $(44,05)$ daha yüksek olduğu tabloda görülmektedir.

Katılımcıların cinsel tutumlar alt boyutundan aldıkları puanlar cinsiyete göre karşılaştırıldığında anlamlı bir fark oluşturduğu (U=701,00 p<.05) söylenebilir. Ancak sıra ortalamalarına bakıldığında ise erkek öğrencilerin $(39,54)$ aldıkları puanlar ile kız öğrencilerin almış oldukları puanlar(54,76) arasındaki farka bakıldığında bu farklılığın dikkat çekici olduğu görülmektedir.

Katılımcıların bireysel değerler alt boyutundan aldıkları puanlar incelendiğinde yine cinsiyete göre anlamlı bir farkın olduğu görülmektedir( $U=591,00$ $\mathrm{p}<.05)$. Cinsel tutumlar alt boyutunda olduğu gibi sıra ortalamaları dikkate alındığında kız öğrenciler(56,29) puanla, erkek öğrencilerin $(35,61)$ almış olduğu puandan daha yüksek olması bireysel değerlere kız öğrencilerin daha fazla önem verildiği görülmektedir.

Baş etme gücü alt boyutunda da katılımcıların aldıkları puanlar karşılaştırildığında cinsiyete göre anlamlı bir farkın olduğunu göstermekte$\operatorname{dir}(\mathrm{U}=701,50 \mathrm{p}<.05)$. Sıra ortalamaları dikkate alındığında kız öğrencilerin dürtü kontrolü, cinsel tutumlar ve bireysel değerlerde olduğu gibi baş etme gücü alt boyutunda da aldıkları puanların $(54,76)$ erkek öğrencilerin almış oldukları $(39,55)$ puanlardan daha yüksek olduğu bu durumun ise kız öğrencilerin benlik oluşturmada erkeklere göre daha ileri seviyede olduklarını göstermektedir.

Offer Benlik İmgesi Ölçeği' ni cevaplayan katılımcıların cinsiyet değişkeni farklılığına ilişkin bağımsız örneklemler için 'Mann-Whitney Analizi' sonuçları incelendiğinde beden imgesi, duygusal düzey, çevre uyumu, mesleki eğitim hedefleri ve sosyal ilişkiler boyutunda cinsiyete göre anlamlı farkın olduğu görülmüş ancak ruh sağlığı alt boyutunda ise anlamlı bir farklılık bulunmamıştır. Sonuçlara ilişkin veriler ise aşağıdaki tablo $8^{\prime}$ de gösterilmiştir. 
Tablo 8. Offer Benlik İmgesi Ölçeği' ni cevaplayan katılımcıların cinsiyet değişkeni farklılığına ilişkin bağımsız örneklemler için 'Mann-Whitney Analizi' sonuçlarn

\begin{tabular}{|c|c|c|c|c|c|c|c|}
\hline & Cinsiyet & $\mathbf{N}$ & $\begin{array}{l}\text { Sira } \\
\text { Ortalamaları }\end{array}$ & $\begin{array}{l}\text { Sum of } \\
\text { Ranks }\end{array}$ & $\begin{array}{l}\text { Mann- } \\
\text { Whitney U }\end{array}$ & $\mathbf{Z}$ & $\mathbf{P}$ \\
\hline \multirow{3}{*}{ Beden İmgesi: } & $\mathrm{K} 1 \mathrm{z}$ & 72 & 55,12 & 3968,50 & \multirow{3}{*}{675,50} & & \multirow{3}{*}{0,009} \\
\hline & Erkek & 28 & 38,63 & 1081,50 & & 2604 & \\
\hline & Toplam & 100 & & & & & \\
\hline \multirow{3}{*}{$\begin{array}{l}\text { Duygusal } \\
\text { Düzey: }\end{array}$} & $\mathrm{K} 1 \mathrm{z}$ & 72 & 54,94 & 3956,00 & \multirow{3}{*}{688,00} & & \multirow{3}{*}{0,012} \\
\hline & Erkek & 28 & 39,07 & 1094,00 & & 2523 & \\
\hline & Toplam & 100 & & & & & \\
\hline \multirow{3}{*}{ Çevre Uyumu: } & $\mathrm{K}_{1 z}$ & 72 & 57,32 & 4127,00 & \multirow{3}{*}{517,00} & & \multirow{3}{*}{0,000} \\
\hline & Erkek & 28 & 32,96 & 923,00 & & 3835 & \\
\hline & Toplam & 100 & & & & & \\
\hline \multirow{3}{*}{$\begin{array}{l}\text { Meslek ve Eğitim } \\
\text { Hedefleri: }\end{array}$} & $\mathrm{K} 1 \mathrm{z}$ & 72 & 58,14 & 4186,00 & \multirow{3}{*}{458,00} & & \multirow{3}{*}{0,000} \\
\hline & Erkek & 28 & 30,86 & 864,00 & & 312 & \\
\hline & Toplam & 100 & & & & & \\
\hline \multirow{3}{*}{$\begin{array}{l}\text { Sosyal } \\
\text { İlişkiler: }\end{array}$} & $\mathrm{K} 1 \mathrm{z}$ & 72 & 57,15 & 4114,50 & \multirow{3}{*}{529,50} & & \multirow{3}{*}{0,000} \\
\hline & Erkek & 28 & 33,41 & 935,50 & & 3744 & \\
\hline & Toplam & 100 & & & & & \\
\hline \multirow{3}{*}{ Ruh Sağlığı: } & $\mathrm{K} 1 \mathrm{z}$ & 72 & 52,48 & 3778,50 & \multirow{3}{*}{865,50} & & \multirow{3}{*}{0,265} \\
\hline & Erkek & 28 & 45,41 & 1271,50 & & 1115 & \\
\hline & Toplam & 100 & & & & & \\
\hline \multirow{3}{*}{ Toplam Puan } & $\mathrm{K} 1 \mathrm{z}$ & 72 & 48,67 & 3504,50 & \multirow{3}{*}{876,50} & & \multirow{3}{*}{0,305} \\
\hline & Erkek & 28 & 55,20 & 1545,50 & & 1027 & \\
\hline & Toplam & 100 & & & & & \\
\hline
\end{tabular}

Katılımcların beden imgesi alt boyutundan aldıkları puanlar incelendiğinde cinsiyet boyutunda bir farkın olduğu görülmektedir( $U=675,50 \mathrm{p}<.05)$. Sıra ortalamalarına bakıldığında kız öğrencilerin aldıkları puanların $(55,12)$ erkek öğrencilerin almış oldukları puanlardan $(38,63)$ daha yüksek olduğu görülmüştür.

Katılımcların duygusal düzey alt boyutundan aldıkları puanlar incelendiğinde cinsiyet boyutunda bir farkın olduğu görülmektedir( $U=688,00 \mathrm{p}<.05)$. Sıra ortalamaları incelendiğinde ise kız öğrencilerin aldıkları puanların $(54,94)$ erkek öğrencilerin almış olduğu puanlardan $(39,07)$ daha yüksek olduğu anlaşılmaktadır.

Katılımcıların çevre uyumu alt boyutunda da cinsiyete göre anlamlı bir farkın oluştuğu görülmektedri göstermektedir(U=517,00 p<.05). Sıra ortalamaları dikkate alındığında kı öğrencilerin aldıkları puanlar $(57,32)$ oranında, erkek öğrencilerin puanlarına göre $(32,96)$ daha yüksektir. 
Katılımcıların meslek ve eğitim hedefleri alt boyutundaki puanlar incelendiğinde puanların cinsiyete göre farklılık göstermektedir. Bu sonuç bize cinsiyetler arasında farklılığ göstermektedir(U=458,00 p<.05). Sira ortalamalarına bakıldığında ise kız öğrencilerin aldıkları puanların $(58,14)$ erkek öğrencilerden $(30,86)$ daha yüksek olduğu görülmektedir.

Katılımcların sosyal ilişkiler alt boyutundan aldıkları puanlar cinsiyete göre farklılık göstermektedir( $(\mathrm{U}=529,50 \mathrm{p}<.05)$. Sira ortalamaları incelendiğinde ise kız öğrencilerin aldıkları puanların $(57,15)$ erkek öğrencilerden $(33,41)$ daha yüksek olduğu anlaşılmaktadır.

Cinsiyet açısından bakıldığında katılımcıların ruh sağ lığı alt boyutundan aldıkları puanlar arasında anlamlı bir farkın olmadığı görülmekte$\operatorname{dir}(\mathrm{U}=865,50 \mathrm{p}>.05)$. Sıra ortalamaları dikkate alındığında ise kız öğrencilerin aldıkları puanlar ile $(52,48)$ erkek öğrencilerin almış olduğu puanlar $(45,41)$ karşılaştırıldığında kız öğrencilerin ruh sağlı̆̆ı boyutunda erkeklere göre daha yüksek puan aldıkları görülmüştür.

Katılımcıların almış oldukları toplam puanların genel olarak cinsiyet açısından karşılaştırılması sonucu ise toplam puanlarının( $U=876,50 \mathrm{p}>.05)$. Cinsiyete göre anlamlı bir fark göstermediği görülüyor ancak sira ortalamaları dikkate alındığında kız öğrencilerin aldıkları puanların $(48,67)$ erkek öğrencilerden $(55,20)$ daha düşük olduğu görülmüştür.

\section{H-2 Benlik Saygısında Sınıf Düzeyine Göre Farklılık Göstermektedir.}

Tablo 9. sını düzeyleri değişkenlerine göre, 'Baba Ergen İlişkisi Ölçeği' Sevgi Gösterme alt boyut puan ortalamalarna İlişkin 'Kruskal-Wallis H Analiz' Sonuçları

\begin{tabular}{lclllll}
\hline & Sinif Düzeyi & N & Sira Ortalamalan & X2 & df & P \\
\hline \multirow{3}{*}{ Sevgi } & 5. Sinff & 25 & 51,94 & & & \\
Gösterme & 6. Sinf & 25 & 48,32 & & & \\
& 7. Sinf & 25 & 51,26 & 0,220 & 3 & \multirow{2}{*}{974} \\
& 8. Sinff & 25 & 50,48 & & & \\
Toplam & 100 & & & & \\
\hline
\end{tabular}

Tablo 9 incelendiğinde, sınıf düzeyi değişkenlerine göre ‘Baba Ergen İlişkisi Ölçeğgi' puanlarının anlamlı bir farklılık gösterip göstermediğini belirlemek amacıyla yapılan 'Kruskal Wallis-H Analizi' sonucunda sevgi gösterme boyutunda sınıf düzeyi gruplarının sıralamalar ortalamalarından elde edilen puanlar arasında anlamlı bir farklılık görülmemektedir $(x 2=0,220 ; s d=3 ; p>05)$. 
Tablo 10. Sınıf düzeyleri değişkenlerine Göre 'Baba Ergen İlişkisi Ölçeği' Özgürlük Tanıma alt boyut puan ortalamalarna ilişkin 'Kruskal-Wallis- H Analiz' Sonuçlarn

\begin{tabular}{lclllll}
\hline & Sinıf Düzeyi & N & Sira Ortalamaları & X2 & df & P \\
\hline & 5. Sinif & 25 & 54,58 & & & \\
Özgürlük & 6. Sinif & 25 & 48,18 & & & \multirow{2}{*}{475} \\
Tanıma & 7. Sinıf & 25 & 44,12 & 2,501 & 3 & \\
& 8. Sinıf & 25 & 55,12 & & & \\
& Toplam & 100 & & & & \\
\hline
\end{tabular}

Tablo 10 incelendiğinde, sınıf düzeyi değişkenlerine ‘Baba Ergen İlişkisi Ölçeği’ puanlarının anlamlı bir farklılık gösterip göstermediğini belirlemek amaciyla yapılan 'Kruskal Wallis-H' sonucunda özgürlük tanıma boyutunda sınıf düzeyi gruplarının sıralamalar ortalamaları arasındaki fark istatistiksel olarak anlamlı bulunamamıştır ( $\mathrm{x} 2=2,501 ; \mathrm{sd}=3 ; \mathrm{p}>05)$.

Tablo 11. Sınıf düzeyleri değişkenlerine göre 'Baba Ergen İlişkisi Ölçeği' genel ortalama puan ortalamalarnna ilişkin 'Kruskal-Wallis-H' Analiz Sonuçları

\begin{tabular}{lccllll}
\hline & Sinıf Düzeyi & N & $\begin{array}{l}\text { Sira } \\
\text { Ortalamaları }\end{array}$ & X2 & df & P \\
\hline \multirow{4}{*}{ Genel } & 5. Sinıf & 25 & 52,70 & & & \\
Ortalama & 6. Sinıf & 25 & 47,86 & & & \multirow{2}{*}{803} \\
& 7. Sinf & 25 & 47,44 & 0,994 & 3 & \\
& 8. Sinıf & 25 & 54,00 & & & \\
& Toplam & 100 & & & & \\
\hline
\end{tabular}

Tablo 11 incelendiğinde, sınıf düzeyi değişkenlerine ‘Baba Ergen İlişkisi Ölçeği’ puanlarının anlamlı bir farklılık gösterip göstermediğini belirlemek amaciyla yapılan 'Kruskal Wallis-H Analiz' sonucunda genel ortalamalara bakıldığında sınıf düzeyleri açısından grupların almış oldukları sıra ortalamaları arasında anlamlı fark bulunamamıştır ( $x 2=0,994$; $\mathrm{sd}=3$; $\mathrm{p}>05)$.

Tablo 12. Sinff dïzeyleri değişkenlerine 'Offer Benlik İmgesi Ölçeğg' puan ilişkisi aile ilişkileri alt boyut puan ortalamalarnna ilişkin 'Kruskal-Wallis-H Analiz' Sonuçlarn

\begin{tabular}{|c|c|c|c|c|c|c|}
\hline & Sınıf Düzeyi & $\mathbf{N}$ & Sira Ortalamaları & $\mathrm{X} 2$ & df & $\mathbf{P}$ \\
\hline \multirow{5}{*}{$\begin{array}{l}\text { Aile } \\
\text { İlişkileri }\end{array}$} & 5. Sinif & 25 & 54,32 & \multirow{5}{*}{3,385} & \multirow{5}{*}{3} & \multirow{5}{*}{,336 } \\
\hline & 6. Sinif & 25 & 43,68 & & & \\
\hline & 7. Sinif & 25 & 47,30 & & & \\
\hline & 8. Sinif & 25 & 56,70 & & & \\
\hline & Toplam & 100 & & & & \\
\hline
\end{tabular}

Tablo 12 incelendiğinde, sınıf düzeyi değişkenlerine göre aile ilişkileri puanlarının anlamlı bir farklılık gösterip göstermediğini belirlemek amacıyla 
yapılan 'Kruskal Wallis-H Analiz' sonucunda sınıf düzeyleri açısından grupların almış oldukları sıra ortalamaları arasında anlamlı fark bulunamamıştır $(x 2=3,385 ; \mathrm{sd}=3 ; \mathrm{p}>05)$.

Tablo 13. Sinıf dïzeyleri değişkenlerine 'Offer Benlik İmgesi Ölçeği' puan ilişkisi dürtü kontrolï alt boyut puan ortalamalarnna ilişkin 'Kruskal Wallis-H Analiz' Sonuçlan

\begin{tabular}{lccllll}
\hline & Sinıf Düzeyi & N & Sira Ortalamalan & X2 & df & P \\
\hline \multirow{4}{*}{ Dürtü } & 5. Sinif & 25 & 44,20 & & & \\
Kontrolü & 6. Sinf & 25 & 46,08 & & & \\
& 7. Sinif & 25 & 58,86 & 4,166 & 3 &, 244 \\
& 8. Sinff & 25 & 52,86 & & & \\
& Toplam & 100 & & & & \\
\hline
\end{tabular}

Tablo 13 incelendiğinde, sinıf düzeyi değişkenlerine göre dürtü kontrolü puanlarının anlamlı bir farklılık gösterip göstermediğini belirlemek amacıyla yapılan 'Kruskal Wallis-H Analiz' sonucunda sınıf düzeyleri açısından grupların almış oldukları sıra ortalamaları arasında anlamlı fark bulunamamıştır $(x 2=4,166 ; s d=3 ; p>05)$.

Tablo 14. Sınıf düzeyleri değişkenlerine 'Offer Benlik Imgesi Ölçeği' puan ilişkisi cinsel tutumlar alt boyut puan ortalamalarnna ilişkin 'Kruskal Wallis-H Analiz' Sonuçlan

\begin{tabular}{lccllll}
\hline & Sinif Düzeyi & N & Sira Ortalamalar & X2 & df & P \\
\hline \multirow{4}{*}{ Cinsel } & 5. Sinif & 25 & 54,48 & & & \\
Tutumlar & 6. Sinf & 25 & 52,66 & & & \\
& 7. Sinif & 25 & 50,42 & 1,778 & 3 & \multirow{2}{*}{620} \\
& 8. Sinff & 25 & 44,44 & & & \\
& Toplam & 100 & & & & \\
\hline
\end{tabular}

Tablo 14 incelendiğinde, sinıf düzeyi değişkenlerine göre cinsel tutumlar puanlarının 'Kruskal Wallis-H Analiz' sonucunda sınıf düzeyleri açısından grupların almış oldukları sıra ortalamaları arasında anlamlı fark bulunamamıştır ( $x 2=1,778 ; \mathrm{sd}=3 ; \mathrm{p}>05)$.

Tablo 15. Sinff düzeyleri değişkenlerine 'Offer Benlik İmgesi Ölçeği' puan ilişkisi bireysel değerler alt boyut puan ortalamalarna ilişkin 'Kruskal Wallis-H Analiz' Sonuçlarn

\begin{tabular}{|c|c|c|c|c|c|c|}
\hline & Sınıf Düzeyi & $\mathbf{N}$ & $\begin{array}{l}\text { Sira Orta- } \\
\text { lamaları }\end{array}$ & $\mathrm{X} 2$ & df & $\mathbf{P}$ \\
\hline \multirow{5}{*}{$\begin{array}{l}\text { Bireysel } \\
\text { Değerler }\end{array}$} & 5. Sinif & 25 & 52,12 & \multirow{5}{*}{0,731} & \multirow{5}{*}{3} & \multirow{5}{*}{,866 } \\
\hline & 6. Sinif & 25 & 46,70 & & & \\
\hline & 7. Sinif & 25 & 50,14 & & & \\
\hline & 8. Sinf & 25 & 53,04 & & & \\
\hline & Toplam & 100 & & & & \\
\hline
\end{tabular}


Tablo 15 incelendiğinde, sinıf düzeyi değişkenlerine göre bireysel değerler puanlarının 'Kruskal Wallis-H Analiz' sonucunda sınıf düzeyleri açısından grupların almış oldukları sıra ortalamaları arasında anlamlı fark bulunamamıştır ( $x 2=0,731 ; \mathrm{sd}=3 ; \mathrm{p}>05)$.

Tablo 16. Sinnf dïzeyleri değişkenlerine 'Offer Benlik İmgesi Ölçeği' puan ilişkisi baş etme gücü alt boyut puan ortalamalarna ilişkin 'Kruskal Wallis-H Analiz' Sonuçları

\begin{tabular}{lclllll}
\hline & Sinıf Düzeyi & N & Sira Ortalamaları & X2 & df & P \\
\hline \multirow{3}{*}{ Bașetme } & 5. Sinıf & 25 & 51,54 & & & \\
Gücü & 6. Sinff & 25 & 44,44 & & & \\
& 7. Sinif & 25 & 52,62 & 1,588 & 3 &, 662 \\
& 8. Sinıf & 25 & 53,40 & & & \\
& Toplam & 100 & & & & \\
\hline
\end{tabular}

Tablo 16 incelendiğinde, sınıf düzeyi değişkenlerine göre baş etme gücü puanlarının 'Kruskal Wallis-H Analiz' sonucunda sınıf düzeyleri açısından grupların almış oldukları sıra ortalamaları arasında anlamlı fark bulunamamiştır ( $x 2=1,588 ; \mathrm{sd}=3 ; \mathrm{p}>05)$.

Tablo 17. Sinnf düzeyleri değişkenlerine 'Offer Benlik İmgesi Ölçeğg' puan ilişkisi beden imgesi alt boyut puan ortalamalarnna ilişkin 'Kruskal Wallis-H Analiz' Sonuçlan

\begin{tabular}{lclllll}
\hline & Sinuf Düzeyi & N & Sira Ortalamalan & X2 & df & P \\
\hline \multirow{4}{*}{ Beden } & 5. Sinif & 25 & 52,30 & & & \\
İmgesi & 6. Sinif & 25 & 42,98 & & & \multirow{2}{*}{350} \\
& 7. Sinif & 25 & 49,48 & 3,285 & 3 & \\
& 8. Sinf & 25 & 57,24 & & & \\
& Toplam & 100 & & & & \\
\hline
\end{tabular}

Tablo 17 incelendiğinde, sınıf düzeyi değişkenlerine göre beden imgesi puanlarının 'Kruskal Wallis-H Analiz' sonucunda sınıf düzeyleri açısından grupların almış oldukları sıra ortalamaları arasında anlamlı fark bulunamamiştır $(x 2=3,285 ; \mathrm{sd}=3 ; \mathrm{p}>05)$.

Tablo 18. Sinnf düzeyleri değişkenlerine 'Offer Benlik İmgesi Ölçeği' puan ilişkisi duygusal diizey alt boyut puan ortalamalarna ilişkin 'Kruskal Wallis-H Analiz' Sonuçlan

\begin{tabular}{lclllll}
\hline & Sınıf Düzeyi & N & Sıra Ortalamaları & X2 & df & P \\
\hline \multirow{4}{*}{ Duygusal } & 5. Sinif & 25 & 43,16 & & & \\
Düzey & 6. Sinıf & 25 & 46,10 & & & \\
& 7. Sinif & 25 & 54,08 & 4,781 & 3 & \multirow{2}{*}{189} \\
& 8. Sinif & 25 & 58,66 & & & \\
& Toplam & 100 & & & & \\
\hline
\end{tabular}

Tablo 18 incelendiğinde, sınıf düzeyi değişkenlerine göre duygusal düzey puanlarının 'Kruskal Wallis-H Analiz' sonucunda sınıf düzeyleri açısından 
grupların almış oldukları sıra ortalamaları arasında anlamlı fark bulunamamiştır $(x 2=4,781 ; \mathrm{sd}=3 ; \mathrm{p}>05)$.

Tablo 19. Stnıf dïzeyleri değişkenlerine 'Offer Benlik İmgesi Ölçeği' puan ilişkisi çevre uyumu alt boyut puan ortalamalarnna ilişkin 'Kruskal Wallis-H Analiz' Sonuçlar

\begin{tabular}{lccllll}
\hline & Sinıf Düzeyi & N & Sira Ortalamalan & X2 & df & P \\
\hline \multirow{4}{*}{ Çevre } & 5. Sinf & 25 & 54,10 & & & \\
Uyumu & 6. Sinif & 25 & 49,20 & & & \multirow{2}{*}{619} \\
& 7. Sinıf & 25 & 53,86 & 1,783 & 3 & \\
& 8. Sinif & 25 & 44,84 & & & \\
& Toplam & 100 & & & & \\
\hline
\end{tabular}

Tablo 19 incelendiğinde, sınıf düzeyi değişkenlerine göre çevre uyumu puanlarının 'Kruskal Wallis-H Analiz' sonucunda sınıf düzeyleri açısından grupların almış oldukları sıra ortalamaları arasında anlamlı fark bulunamamiştır ( $x 2=1,783$; sd=3; $>05)$.

Tablo 20. Sinıf dïzeyleri değişkenlerine 'Offer Benlik İmgesi Ölçeği' puan ilişkisi Meslek ve Eğitim Hedefleri alt boyut puan ortalamalarnna ilişkin 'Kruskal Wallis-H Analiz' Sonuçları

\begin{tabular}{lclllll}
\hline & Sinıf Düzeyi & N & Sıra Ortalamaları & X2 & df & P \\
\hline \multirow{4}{*}{ Meslek ve Eğitim } & 5. Sinıf & 25 & 53,60 & & & \\
Hedefleri & 6. Sinıf & 25 & 50,88 & & & \multirow{2}{*}{892} \\
& 7. Sinıf & 25 & 50,20 & 0,619 & 3 & \\
& 8. Sinf & 25 & 47,32 & & & \\
& Toplam & 100 & & & & \\
\hline
\end{tabular}

Tablo 20 incelendiğinde, sınıf düzeyi değişkenlerine göre Meslek ve Eğitim Hedefleri puanlarının 'Kruskal Wallis-H Analiz' sonucunda sinıf düzeyleri açısından grupların almış oldukları sıra ortalamaları arasında anlamlı fark bulunamamıştır $(x 2=0,619 ; \mathrm{sd}=3 ; \mathrm{p}>05)$.

Tablo 21. Sinıf düzeyleri değişkenlerine 'Offer Benlik İmgesi Ölçeği' puan ilişkisi Sosyal İlişkiler alt boyut puan ortalamalarna ilişkin 'Kruskal Wallis-H Analiz' Sonuçlan

\begin{tabular}{lclllll}
\hline & Sınıf Düzeyi & N & Sıra Ortalamaları & X2 & df & P \\
\hline \multirow{4}{*}{ Sosyal } & 5. Sinf & 25 & 51,34 & & & \\
İlişkiler & 6. Sinıf & 25 & 51,52 & & & \\
& 7. Sinıf & 25 & 49,94 & 0,116 & 3 &, 990 \\
& 8. Sinıf & 25 & 49,20 & & & \\
& Toplam & 100 & & & & \\
\hline
\end{tabular}

Tablo 21 incelendiğinde, sınıf düzeyi değişkenlerine göre Sosyal İlişkiler puanlarının 'Kruskal Wallis-H Analiz' sonucunda sınıf düzeyleri açısından 
grupların almış oldukları sıra ortalamaları arasında anlamlı fark bulunamamiştir ( $x 2=0,116$; $\mathrm{sd}=3$; $\mathrm{p}>05)$.

Tablo 22. Sinuf düzeyleri değişkenlerine 'Offer Benlik İmgesi Ölçeği' puan ilişkisi Ruh sağhğ̆ alt boyut puan ortalamalarna ilişkin 'Kruskal Wallis-H Analiz' Sonuçları

\begin{tabular}{lclllll}
\hline & Sinff Düzeyi & N & Sira Ortalamaları & X2 & df & P \\
\hline \multirow{4}{*}{ Ruh } & 5. Sinıf & 25 & 44,40 & & & \\
Sağlı̆̆ı & 6. Sinf & 25 & 61,22 & & & \multirow{2}{*}{370} \\
& 7. Sinıf & 25 & 46,48 & 3,147 & 3 & \\
& 8. Sinıf & 25 & 49,90 & & & \\
& Toplam & 100 & & & & \\
\hline
\end{tabular}

Tablo 22 incelendiğinde, sinıf düzeyi değişkenlerine göre Ruh Sağlığı puanlarının 'Kruskal Wallis-H Analiz' sonucunda sınıf düzeyleri açısından grupların almış oldukları sıra ortalamaları arasında anlamlı fark bulunamamiştır ( $x 2=3,147$; sd=3; $>05)$.

Tablo 23. Stnff dïzeyleri değişkenlerine 'Offer Benlik İmgesi Ölçeği' puan ilişkisi toplam puan ortalamalarna ilişkin 'Kruskal Wallis-H Analiz' Sonuçlarn

\begin{tabular}{lclllll}
\hline & Sinıf Düzeyi & N & Sira Ortalamaları & X2 & df & P \\
\hline \multirow{4}{*}{ Toplam } & 5. Sinıf & 25 & 44,40 & & & \\
Puan & 6. Sinif & 25 & 61,22 & & & \\
& 7. Snif & 25 & 46,48 & 5,182 & 3 &, 159 \\
& 8. Sinff & 25 & 49,90 & & & \\
& Toplam & 100 & & & & \\
\hline
\end{tabular}

Tablo 23 incelendiğinde, sinıf düzeyi değişkenlerine göre toplam puanlarının 'Kruskal Wallis-H Analiz' sonucunda sınıf düzeyleri açısından grupların almış oldukları sıra ortalamaları arasında anlamlı fark bulunamamıştır $(x 2=5,182 ; s d=3 ; p>05)$.

\section{H-3 Babalık Rolü Algısında Babanın Eğitim Düzeyinin Etkisi Vardır.}

Tablo 24. Babaların Eğitim durumları değişkenlerine Göre 'Babalık Rolü Algısı Ölçeği' puan ortalamalarna ilişkin 'Kruskal Wallis-H Analiz' Sonuçları

\begin{tabular}{cllllll}
\hline \multicolumn{2}{c}{ Babanın Eğitim Durumu } & N & Sıra Ortalamaları & X2 & df & P \\
\hline & İlkokul & 9 & 51,44 & & & \\
& Ortaokul & 17 & 59,06 & & & \\
Babalık Rolü & Lise & 32 & 48,83 & 1,918 & 4 &, 751 \\
& Ön lisans & 14 & 47,25 & & & \\
& Lisans & 28 & 48,54 & & & \\
& Toplam & 100 & & & & \\
\hline
\end{tabular}


Tablo 24 incelendiğinde, babalarnn eğitim durumu değişkenlerine göre ‘Babalık Rolü Algısı Ölçeği' puanlarının 'Kruskal Wallis-H Analiz' sonucunda babaların çocuklarının eğitim düzeyi gruplarına yönelik babalık rolü algısına vermiş oldukları puanların ortalamalarına bakıldığında fark bulunamamıştır $(\mathrm{x} 2=1,918 ; \mathrm{sd}=4 ; \mathrm{p}>05)$.

\section{H-4 Babalık Rolü Algısında, Çocuğunun Sınıf Düzeyiyle İlgisi Vardır}

Tablo 25. Sınıf düzeyleri değişkenlerine göre 'Babalık Rolü Algısı Ölçeği' puan ortalamalarnna ilişkin 'Kruskal Wallis-H Analiz' Sonuçları

\begin{tabular}{|c|c|c|c|c|c|c|}
\hline \multicolumn{2}{|c|}{ Çocuğunun Bulunduğu Sınıf Düzeyi } & \multirow{2}{*}{$\begin{array}{l}\mathbf{N} \\
25\end{array}$} & \multirow{2}{*}{$\begin{array}{l}\text { Sira Ortalamaları } \\
58,02\end{array}$} & \multirow[t]{2}{*}{$\mathrm{X} 2$} & \multirow[t]{2}{*}{$\mathrm{df}$} & \multirow[t]{2}{*}{$\mathbf{P}$} \\
\hline \multirow{5}{*}{ Babalık Rolü } & 5. Sinif & & & & & \\
\hline & 6. Sinif & 25 & 45,30 & \multirow{4}{*}{2,719} & \multirow{4}{*}{3} & \multirow{4}{*}{ 437 } \\
\hline & 7. Sinif & 25 & 50,82 & & & \\
\hline & 8. Sinif & 25 & 47,86 & & & \\
\hline & Toplam & 100 & & & & \\
\hline
\end{tabular}

Tablo 25 incelendiğinde, 5,6,7, ve 8 . Sınıfta çocuğu bulunan babaların sınıf değişkenlerine göre 'Babalık Rolü Algısı Ölçeği' puanlarının anlamlı bir farklılık gösterip göstermediğini belirlemek amacıyla yapılan ‘Kruskal Wallis- $\mathrm{H}$ Analiz' sonucunda babaların, çocuklarının sınıf düzeylerinin sıralamalar ortalamaları arasındaki fark istatistiksel olarak anlamlı bulunamamıştır $(x 2=2,719 ; \mathrm{sd}=3 ; \mathrm{p}>05)$.

\section{Tartışma ve Sonuç}

Araştırmadan elde edilen bulgulara göre; benlik saygısında cinsiyetlere göre farklılık vardır(H1) hipotezi değerlendirildiğinde; sevgi gösterme, özgürlük tanıma boyutunda anlamlı bir farklılığın olmadığı görülmüştür. Ancak genel ortalama puanına bakıldığında ise, kız öğrencilerin ortalama puanların erkek öğrencilerden daha düşük olması sevgi ve özgürlük konusunda erkeklerin daha avantajlı olduğu söylenebilir. Erkek ergenlerin kız ergenlere göre babalarıyla daha yakın ilişki kurmaları ve babalarının erkek çocuklarına daha fazla özgürlük tanımalarına rağmen kız ergenlerin benlik saygılarının ve bu benlik saygısını oluşturan alt unsurların erkek ergenlere göre daha fazla olumlu gelişme göstermiş olduğu görülmektedir. Buna göre, benlik saygıs1nın gelişmesinde babaları ile kız ergenlerin ilişki düzeylerinin erkeklere göre yüzeysel olduğu sonucuna varılabilir. Yukarıda da bahsedildiği üzere, değişen sosyal ve ekonomik şartlara bağlı olarak aile içi rollerin değişmesiyle bir- 
likte babaların da çocuklarıyla daha fazla ilgilenme gerekliliği ortaya çıkmıştır. Bu konuda yapılan araştırmalara bakıldı̆̆ında babanın çocuklarının çok yönlü olarak gelişimleri üzerindeki olumlu etkileri olduğu bilinmektedir. Ancak bu araştırmada; ergenin benlik saygısı üzerinde babası ile ilişkisinin anlamlı şekilde etkisinin olmadığı bulgusu ile geleneksel baba rolü algısının ilgili olduğu sonucuna varılabilir. Zira babalık rolündeki değişime uyum her kesimde aynı düzeyde olmamaktadır. Büyük kentlerde gelişim ve değişimin daha hızlı olabilir ancak küçük ve değişime dirençli illerde hala geleneksel baba rolünün sürdürüldüğü görülmektedir.

Cinsel turumlar, bireysel değerler ve baş etme gücü, beden imgesi, duygusal düzey, çevre uyumu, mesleki eğitim hedefleri ve sosyal ilişkiler boyutunda cinsiyete göre anlamlı farkın olduğu görülmüş̧ür. Kız ergenlerin erkek ergenlere göre daha yüksek puanlar aldıkları bulunmuştur. Buna göre, kızlar ailesi ve çevresiyle daha uyumlu ve iyi ilişkiler kurabilen, dürtü kontrolüne daha sahip, zorluklarla baş etme gücü daha yüksek, bireysel değerinin daha çok farkında olan, cinsel eğilime karşı tutumları daha fazla gelişmiş, daha olumlu beden imgesine sahip, gelecek hedeflerine daha fazla yönelen ve daha duygusal olduklarını söyleyebiliriz.

Ayrıca kız ve erkek ergenlerin ruhsal sağlığı alt boyutunda birbirine yakın puanlar almış olmaları da manidar olarak görülmektedir. Tüm bu araştırma ve bulgular ışı̆̆ında, ortaokul çağında yani ön ergenlik dönemindeki öğrencilerin benlik saygılarında babaları ile ilişkilerinin cinsiyet, sınıf düzeyi ve babanın eğitim durumuna göre önemli düzeyde farklılık göstermediği görülmüsstür. Ancak aile sağlı̆̆ı, dürtü kontrolü ve ruh sağlığı alt boyutlarında ise anlamlı bir farklılık olmadığı görülmüştür. Bu alt boyut puanlarının genel ortalamasına bakıldığında ise kız öğrencilerin erkek öğrencilere göre daha benlik saygısı oluşturmada daha önde oldukları sonucuna ulaşılmıştır.

Bulgular, benlik saygısında sinıf düzeyine göre farklılık göstermekte$\operatorname{dir}(\mathrm{H} 2)$ hipotezine göre değerlendirildiğinde sevgi gösterme ve özgürlük tanıma, aile ilişkileri, dürtü kontrolü, cinsel tutumlar, bireysel değerler, başetme gücü, beden imgesi, duygusal düzey, çevre uyumu, meslek ve eğitim hedefleri, sosyal ilişkiler ve ruh sağlığ 1 boyutlarında anlamlı bir farklılık görülmemiştir. Araştırma bulguları babanın eğitim düzeyinin babalık rolü algısındaki etkisi değerlendirildiğinde babaların çocuklarının eğitim düzeyi gruplarına yönelik babalık rolü algısına vermiş oldukları puanlar arasında farklılık gözlenmemiştir. Çocuğunun sınıf düzeyinin babalık rolü algısındaki 
ilgisine bakıldığında da babaların, çocuklarının sınıf düzeyleri arasındaki fark istatistiksel olarak anlamlı bulunmamıştır. Araştırma bulguları genel olarak değerlendirildiğinde ve Recepov (2000)' de belirtildiği üzere ülkemizde 1991 yılında yapılan bir çalışmada aile içi ilişkilerde cinsiyete ilişkin farklılıklar dikkat çekmektedir. Bu çalışmada, Türk gençlerinde anneyle olan ilişkinin önemi vurgulanmış ve annelerin her iki cinsle de ilişkilerinin yüksek olduğu belirtilirken, babaların erkek çocuklarıyla kız çocuklarına göre daha yakın iliş̧i kurdukları görülmüştür. Ergenlerin benlik saygıları üzerinde babaları ile kurdukları ilişkinin etkisini belirlemeye yönelik yapılan bu araştırmada da yine benzer bulgular elde edilmiştir. Geleneksel aile kültüründe babanın para kazanan ve ailenin bakımını sağlayan rol algısı ağırlık kazanması nedeniyle erkek çocuğun benlik oluşturma çabaları babadan ziyade akran grupları arasında sürdürülmeye çalışılmaktadır. Ancak akran gruplarında ve çevresindeki bulunan olumsuz rol modellerden korumak amacıyla erkek ergenin benlik saygısını oluştururken babasıyla birlikte sağlıklı şekilde yürütebilmesine ihtiyaç duyulmaktadır. Eğitimde babalara kendi rolleri ile algılarının yeniden yapılandırılması, ergen psikolojisi gibi konularda bilgilendirme yapılabilir. Babaların, erkek çocuklarının benlik kavramlarına ve özgüvenlerine katkıda bulunabilecek nitelikte aktivitelerin bulunacağı etkinlikler düzenlenebilir.Bu doğrultuda; Erkek ergenlerde benlik saygısının olumlu yönde gelişmesini sağlamak amacıyla babanın olumlu rol model olabileceği şekilde eğitimler düzenlenmelidir. Bu eğitimler babanın çalışma zamanlarına göre planlanmalı ve babaların katılımı sağlanmalıdır. Eğitimde babalara kendi rolleri ile algılarının yeniden yapılandırılması, ergen psikolojisi gibi konularda bilgilendirme yapılabilir. Babaların, erkek çocuklarının benlik kavramlarına ve özgüvenlerine katkıda bulunabilecek nitelikte aktivitelerin bulunacağı etkinlikler düzenlenebilir. Eğitimde babaların

- Ergenlik döneminde kız ve erkek çocuğun babası ile ilişkisinin önemi

- Ergenin benlik saygısı ve kimlik oluşturmada aile içi iletişimin önemi

- Gelişen ve değişen toplum yapısında babalık rolü algısında da değişim olması gerekliliği

- Ergende olumlu benlik gelişmesi için aile içinde yapılabilecekler gibi konularda bilgi vermeye yönelik olarak her sınıf düzeyi için ayrı ayrı oturumlar yapilabilir.

- Ergenin benlik saygısını geliştirme ile ilgili senaryolar oluşturulup babaçocuk rol canlandırması şeklinde etkinlikler düzenlenebilir. 


\title{
EXTENDED ABSTRACT
}

\section{Review Of Self-Esteem At Secondary School Age With Respect To Gender, School Grade Level, Per-ception Of Fathering Role And Educational Level}

\author{
Havva Özkan \\ Istanbul Aydın University
}

The individual goes through periods from birth to old age, each of which includes different developmental tasks. Each period shows its own characteristics that should be examined separately. However, the adolescence has always been within the interest of science and studied from different aspects as an important period. The adolescent tries to form his own personality structure by criticizing some social rules he encounters in his environment and adapting to others and to develop a self-concept for this. The effect of moral development is also seen in relationships with the environment and also in self-esteem of the individual. A study which reviewed the Effects Families' Attitudes and Behaviors on the Adolescents' Self-Esteem suggest that those adolescents who have good relations with the family, participate in decisions, receive respect in terms of views, face no gender discrimination, talk with the family about everything and have democratic families have higher self-esteem.

In this study, the Relational Scanning Model was used in accordance with the purpose of the research. The research sample comprise randomly selected $5^{\text {th }}, 6^{\text {th }}, 7^{\text {th }}$ and $8^{\text {th }}$ class students -in 2019-2020 school year from- at 75. Y1l Mühibe Germirli Secondary School, Erciyes Secondary School, Kadir Has Secondary School located in the city center of Kayseri, Turkey. 100 students and fathers replied the scale. 'Spearman Correlation Analysis" was conducted regarding the significant relationship between the sub-dimensions of the ' Offer Self-Image Scale' of the participants. 'Kruskal- Wallis H Analysis' was conducted for independent samples regarding the educational status and class variables of the participants who answered the 'Perception of Fatherhood Role Scale'. A 'Mann- Whitney Analysis' was conducted for independent 
samples regarding the gender level variables of the participants who answered the ' Adolescent-Father Relationship Scale'. Analysis of the participant fathers' educational status indicate that $9 \%$ of the participants graduated from Primary School, 17\% from Middle School, 32\% from High School, 14\% have Associate Degree and 28\% have undergraduate degree, while 59\% and $41 \%$ of the participants taking the Adolescent-Father Scale were male and female students, respectively. Additionally, ratio of male and female participants the Offer Self-Image Scale were $72 \%$ and $28 \%$, respectively. Regarding the hypothesis that self-esteem significantly differs depending on the gender (H1), the findings indicate no significant difference in showing love and allowing freedom sub-dimensions. However, looking at the general average score, it can be said that the lower average scores of female students than male students are more advantageous for males in terms of love and freedom. Although male adolescents have closer relationships with their fathers and their fathers allow their boys more freedom than female adolescents, it is seen that female adolescents' self-esteem and the sub-elements that make up this self-esteem show more positive development compared to male adolescents. Accordingly, regarding the development of self-esteem, it can be concluded that the relationship levels of fathers with their adolescent daughters are superficial compared to that with their sons.

It has been observed that there is a significant difference by gender in the dimensions of sexual attitudes, individual values and coping power, body image, emotional level, environmental adaptation, vocational education goals, and social relations. It was found that female adolescents got higher scores than male adolescents. In addition, it is meaningful that male and female adolescents have similar scores in the mental health sub-dimension. In the light of all these researches and findings, it has been observed that there is no significant difference in the self-esteem relationships of middle school students with their fathers according to gender, grade level and father's education level. However, there was no significant difference in family health, impulse control and mental health sub-dimensions. Looking at the general average of these sub-dimension scores, it was concluded that female students were ahead in creating self-esteem than male students. When the findings are evaluated on the basis of the 'self-esteem differ by class level (H2)' hypothesis, it is seen that there is no significant difference in showing love and allowing freedom, family relationships, impulse control, sexual attitudes, individual values, coping power, 
body image, emotional level, environmental harmony, professional and educational goals, social relations and mental health dimensions. According to the findings of the study, when the effect of the father's education level on the perception of the fatherhood role was evaluated, no difference was observed between the scores that fathers gave to the perception of the fatherhood role for their children's education level groups. Considering the relationship between the class level of their child in the perception of the fatherhood role, the difference between fathers and their children's class levels was not found to be statistically significant. When the findings of the study are evaluated in general, in order to protect from the negative role models in and around peer groups, male adolescents need to go through with their father in a healthy way while creating self-esteem. In this direction; In order to improve self-esteem in male adolescents, trainings should be organized in a way that the father can be a positive role model. These trainings should be planned considering the working times of the father and the participation of the fathers should be ensured. In education, fathers can be informed about the restructuring of their roles and perceptions, adolescent psychology. Activities can be organized for fathers to contribute to self-concept and self-confidence of their sons.

\section{Kaynakça / References}

Aksoy, A.B. ve Tatlı, S.(2019). Okul öncesi dönem çocuğu olan babaların çocuklarıyla olan ilişkileri ile babalık rolü algıları arasındaki ilişkinin bazı değişkenler açısından incelenmesi. ÇKÜ Sosyal Bilimler Enstitüsü Dergisi, 10, 1-22.

Başaran, A.R. (1984). Kırsal kesimde: aile kurma çözme, aile içi etkileşim ve ilişkiler. Türkiye'de Ailenin Değişimi Toplum bilimsel Incelemeler. Ankara: Maya Matbaacilik.

Bozyiğit, S. (2015). Üniversite öğrencilerinin tüketim sürecine etki eden sosyalleşme aracılarının öğrencilerin materyalist eğilimi ve marka bilinci üzerindeki etkisine yönelik bir pilot çalışma. Ç.Ü. Sosyal Bilimler Enstitüsü Dergisi, 24(2), 295-302.

Cloutier, R. (2019). Ergenlik psikolojisinde kuramlar. (Onur, B, Çev). Ankara University Journal of Faculty of Educational Sciences (JFES) , 27(2) , 875-904 . DOI: 10.1501/Egifak_0000000360

Çuhadaroğlu, F., Sonuvar, B. \&Özusta, S. (1992). Offer Kendilik İmgesi ölçeği uyarlama çalışması. VII. Ulusal Psikoloji Kongresi Bilimsel Çalışmaları. Ankara: 137-141. 
Dilek, H. ve Aksoy, A.B. (2013). Ergenlerin benlik saygisı ile anne-babalarının benlik saygısı arasındaki ilişkinin incelenmesi. Ahi Evran Üniversitesi Kırşehir Ĕ̆itim Fakültesi Dergisi (KEFAD), 14(3), 95-109.

Dinçel, E. (2006). Ergenlik dönemi gelişimsel ödevleri ve psikolojik problemler. Yayınlanmamış Yüksek Lisans Tezi. Ankara Üniversitesi. Ankara.

Erbil, N., Divan Z. ve Önder, P.(2006). Ergenlerin benlik saygısina ailelerinin tutum ve davranışlarının etkisi. Sosyal Politika Çalışmaları Dergisi, 3(10),7-16.

Geçtan, E .(1981). Psikanaliz ve sonrası. İstanbul: Hür Yayınları.

Hortaçsu, N. (1997). İnsan ilişkileri. Ankara: İmge Kitabevi.

Karagöz, S. (2020). Cumhuriyet Dönemi eğitimine yön veren yerli ve yabancı uzman raporları 1911-1926. (3. Baskı). Ankara: Pegem Yayınları.

Karagöz, S. (2018). İkinci meşrutiyetten harf inklabına süreli yayınlarda eğitim (1908-1928). Ankara: Vize Yayıncllik.

Karagöz, S. (2016). Opinions and suggestions regarding various subjects on the educational guidance in the second constitutional era. Journal of Family, Counseling, and Education, 1, 1-9. https://doi.org/10.32568/ffce.834687

Koç, M. (2004). Gelişim psikolojisi açısnndan ergenlik dönemi ve genel özellikleri, Uludağ Üniversitesi Sosyal Bilimler Enstitüsü Dergisi. 2(1), 231-256.

Kulaksızoglu, A. (1998). Ergenlik psikolojisi. İstanbul: Remzi Yayınevi.

Kuruçay, R. (2012). Babanın durumsal ve kişilik özellikleriyle erkek ergen çocuklarmm gerçekleştirdiğgi kuraldışı davranışlarn türü arasındaki ilişkinin incelenmesi. Yayınlanmamış Yüksek Lisans Tezi, Maltepe Ü. İstanbul.

Kuzucu, Y.(1999). Babalarnyla çatışma düzeyi yüksek ve düşük olan ergenlerin ve babalarnnn babahk rolüne ilişkin algllarnmn karşılaştırlması. Yayınlanmamış Yüksek Lisans Tezi, Ankara Ü. Sosyal Bilimler Enstitüsü, Ankara.

Küçük, O. (2016). Bilimsel araştırma yöntemleri. Bursa: Ekin Yayınevi.

Onur, B. (1997). Gelişim psikolojisi. Ankara: İmge Kitabevi

Öngen, D. (2004). Özerklik kazanma sürecinde ergen-anne ile ergen-baba ilişkileri arasindaki farklılıklar, Eğitim ve Bilim. 29( 131), 3-13.

Pişkin, M. ve Kuzgun, Y.(Ed.) İköğretimde rehberlik. Ankara: Nobel Akademik Yayincilik.

Recepov, R. (2000). Alģlanan ana-baba davranışlart: kültü̈rler arası bir karşılaştırma. Yayınlanmamış Yüksek Lisans Tezi. Ankara Ü. Sosyal Bilimler Enstitüsü, Ankara.

Sancar, N. (2017). Alglanan baba tutumu ve benlik saygısı arasındaki ilişki. Yayınlanmamış Yüksek Lisans Tezi, Maltepe Ü.İstanbul.

Senemoğlu, N. (1997). Gelişim, öğrenme ve öğretim. Ankara: Spot Matbaacllk. 
Smith, P.K. (2017). Ergenlik (Çev: Ç. Öztek). Ankara: Türkiye İş Bankası Kültür Yayinları.

Yavuzer, H. (1990). Yaygm ana-baba tutumlan, ana-baba okulu. İstanbul: Remzi Kitabevi. Yörükoğlu, A. (1986). Gençlik çă̆ı. Ankara: Türkiye İş Bankası Kültür Yayınları.

\section{Kaynakça Bilgisi / Citation Information}

Özkan, H. (2021). Ortaokul çağında benlik saygısının cinsiyet, sınıf düzeyi babalık rolü algısı ve eğitim düzeyine göre incelenmesi. OPUSUluslararası Toplum Araştırmaları Dergisi, 17(35), 1755-1784. DOI: 10.26466/opus.787450 